\title{
Specific Features of Personality Changes Among Theatre College Students During the First Year
}

\author{
Vladimir S. Sobkin and Tatiana A. Lykova \\ Russian Academy of Education \\ 8 Pogodinskaya Str., Moscow, 119121, Russia
}

Received 24.08.2014, received in revised form 24.10.2014, accepted 05.11.2014

The article presents the results of a longitudinal research of personal characteristics of actor students, on the base of the Moscow Theater College under the direction of the national artist of USSR O.P. Tabakov. The research started in 2010 and has been conducted up to present days and its work with the scientific program began in 1976. These results were received by $R$. Cattell's 16 PF test. In the research were interviewed 96 actor students. Discussed dynamics of personal change during the first year in the theatre college; the differences between successful and unsuccessful students and the results of structural analysis of the personal characteristics were received by $R$. Cattell's 16 PF test. The obtained results show that during the first year of studying the general direction of students' personality changes is oriented to the increase of emotional sensitivity, motivation and anxiety, as well as to the reduction of radicalism. The major differences between successful and unsuccessful acting students appear in directions of personality changes throughout the first year. One of the important points is the fact of change itself: students who remain static or demonstrate individual changes, which do not coincide with the group tendency, are less successful. The structural analysis of personal characteristics of successful students enabled us to determine two invariant factors: "emotional excitability/control" and "emotional openness", which represent two mandatory features of a successful actor. Other personality scales are subjected to transformation under the influence of external factors and teaching techniques.

Keywords: actor's talent, personal characteristics, psychology of creativity, professional selection.

Research area: pedagogy, psychology.

Analysis of personal changes during studying in theatre institutions is of extremely high importance. As noted by L. Vygotsky (Vygotsky,1984) here one should take these two points into account: the first is concerned with the understanding of historical conditionality of acting, which implies that the question regarding acting abilities and impersonation techniques cannot be stated ultimately (various types of theatre - theatre del arte, theatre of experience, Brecht's theatre etc. - require various "actor-role" relationships, and hence, are directed at different characteristics of an actor as a subject of activity). The second point is related to empirical development of the actor's personality theme, which suggests

(C) Siberian Federal University. All rights reserved

* Corresponding author E-mail address: sobkin@mail.ru 
realization of traditional psychological research within the framework of the general field of labor psychology. Underlying this distinction as introduced by L. Vygotsky, this article presents the materials regarding personality changes during studying at the first year of a theatre college.

It should be preliminary stressed that mastering of acting profession is a hard work for students, especially given the creative layout of the learning process in itself. A very important factor here is the age at which the professional orientation begins. Thus, a theatre college presents a unique institution, where the professional formation of future actors starts at 15-16 years old, which is 2-3 years earlier than in a theatre university. This poses additional tasks to teachers, who have to take into consideration the specific features of later adolescent age during their work. On one hand, this period brings forward the needs for personal and vocational selfdetermination, on the other hand - adolescent age is characterized by egocentrism accompanied by anxiety, vulnerability, susceptibility, insecurity etc. All this inevitably influenced learning progress, atmosphere in the group and students' relationships with teachers and classmates. Detection of personal transformations taking place during studying enables to establish a faster feedback for teachers, which will allow them to help students develop skills and features necessary for the acting profession. Moreover, it is important for diagnostics of relationship between student groups and within a college in general. Lastly, derived information is significant for the work of a psychologist who follows acting students through.

The purpose of present article is to analyze personality changes taking place for students of a theatre college during their first year of studying. The three main directions of research are as follows:
1) To examine the dynamics of personal characteristics' intensity among the firstyear students;

2) To detect personal distinctions between successful and unsuccessful students;

3) To perform a structural analysis of students' personal characteristics at the beginning and at the end the first year of the theatre college.

The results presented are a part of a research project conducted within the collaboration between Moscow Theatre College under the direction of $\mathrm{O}$. Tabakov and the Institute of educational sociology RAE. The program is based on psychological examination of acting students with the help of a variety of testing methods, among which are: R. Cattell test, H. Eysenck test, Rosenzweig test, The Mayer-Salovey-Caruso Emotional Intelligence Test (MSCEIT v.2.0), sociometry, content analysis of study records and some others, as well as several specifically developed techniques for determination of value orientations and artistic preferences. Given the limits of the article, it will only present the data obtained by the R. Cattell test $16 \mathrm{PF}$. The examinations are held several times: at the stage of selection of students before the third round of entry exams and then once at the end of every year. As the purpose of this paper is to analyze the dynamics of personal features specifically during the first year, the presented data is derived from the entry exams stage (first testing) and at the end of the year (second testing).

Sample group: students of Moscow Theatre College under the supervision of O. Tabakov (enrolments of 2010, 2011, 2012 and 2013), in total 96 young people ( 32 girls, 64 boys). It should be emphasized that students who passed the entry exams had gone through a very strict outsourcing, which saw about 2000 contestants at preliminary stages. The analysis of personal characteristics of those who entered the college and those who 
failed was presented in our previous publications (Sobkin, Lykova, 2014).

The collected material is grouped into three sections, which examine the dynamics of students' personality changes, the differences between successful and unsuccessful students and structural analysis of the dynamics of personal characteristics.

Analysis of the dynamics of personality changes for students of a theatre college among enrolments 2010-2013.

To follow the dynamics of personality changes which took place during the first year of studying, we will compare average summary profiles for the Cattell test, which were obtained at the stage of entry exams and at the end of the year (see Fig. 1)

During the previous analysis (Sobkin, Feofanova, 2012), which was based upon the comparison between acting students and a control group of comprehensive school students of the same age, displayed factors (factor A "sociability", factor H "courage", factor I "sensitivity", factor Q2 "conformity") that statistically differentiated the entrants. As shown on the figure, values of these personality factors remained unchanged during the first year. At the same time, statistically significant differences were observed for the three factors: O "anxiety" ( $\mathrm{p}=.03), \mathrm{Q} 1$ "radicalism" $(\mathrm{p}=.05), \mathrm{Q} 4$ "tension" $(\mathrm{p}=.01)$. It is notable that values for anxiety and tension had increased over the first year, whereas radicalism of students was visibly reduced. To interpret these changes we have to note that factors O and Q4 are part of the secondary factor of Cattells test Q2 "anxiety" that registers nervousness in its common meaning. It may characterize the learning process as one which brings forward situations causing stressful emotions. At the same time, the increase of these two values may be viewed as a positive tendency

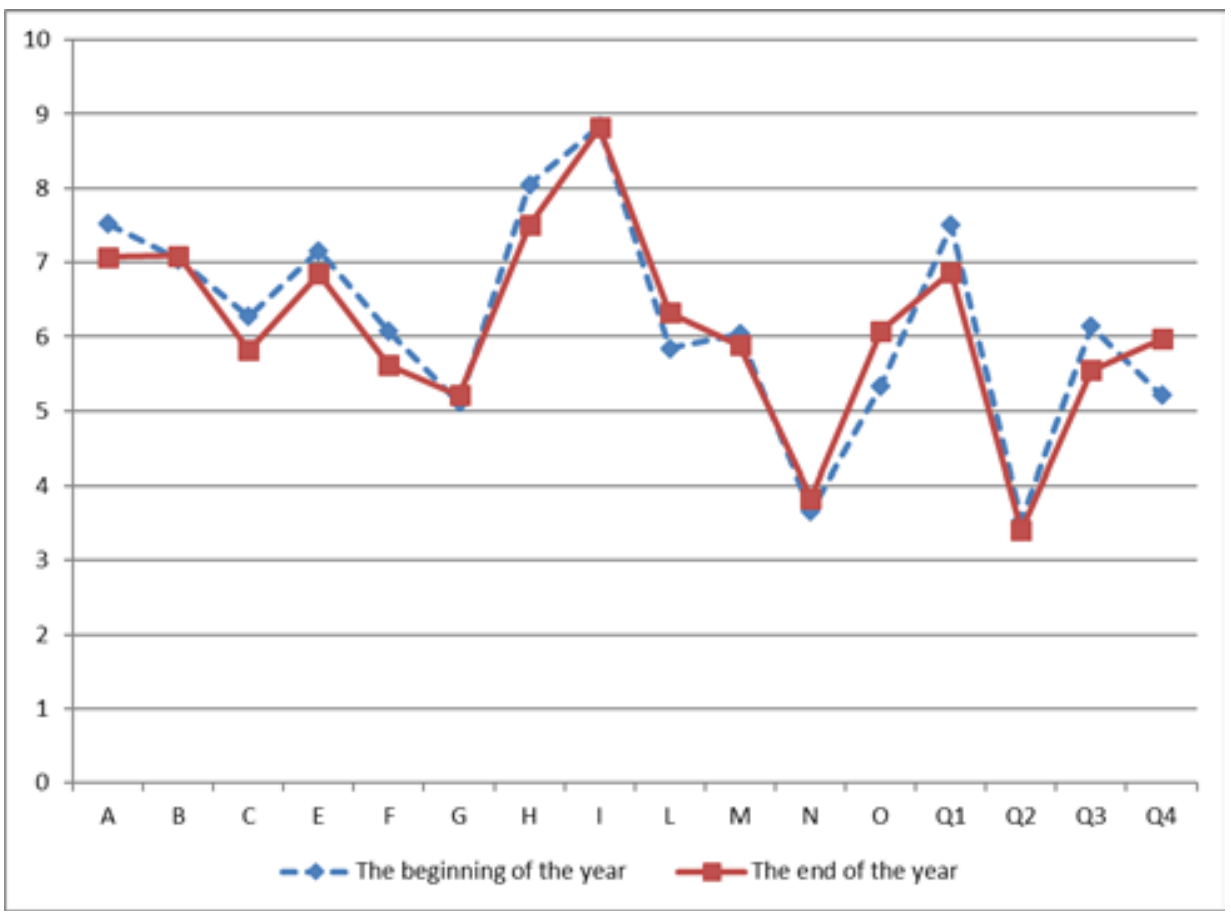

Fig. 1. Average summary profiles for the Cattell test $16 \mathrm{PF}$ at the beginning and at the end of the first year for enrolments 2010-2013 (points in stens) 
attributed to the essence of acting profession. Thus, factor Q4 "tension" at its positive pole represents such characteristics as attentiveness, enthusiasm, increased motivation, and factor $\mathrm{O}$ "anxiety" equally includes uneasiness, concern, vulnerability and dissatisfaction with oneself, which along with increased motivation may be interpreted as a positive aspiration to excel in active work and reach better results. As for the factor Q1 "radicalism", which had decreased by the end of the first year, in our opinion it shows that students, in an attempt to follow teachers' requirements, begin to treat their personal work more thoroughly and critically, as well as develop deeper trust towards teachers and classmates.

The presented changes reflect the general dynamics of students' personal characteristics as a sum for four enrolments (2010, 2011, 2012, and 2013). Yet, it should be stressed that mastering of the acting profession does not only happen individually, but also through group work and collective creation. Acting workshops in the first year generally include group trainings and exercises aimed to improve sense of rhythm, attention, emotional memory and interaction with partners on stage. While organizing the educational process, teachers employ various pedagogical strategies basing on the initial level of ability, readiness for action and motivation among students. Not the last part is played by the atmosphere in the student team. With regard to this, it may be supposed that depending on the specific features of each course teachers will use various working tactics directed to the stimulation of specific personality changes among students.

To prove this hypothesis, we will address the comparison of average summary profiles of students of each enrolment separately. Fig. 2 shows significant dissimilarities which were discovered upon comparing students' average profiles of three enrolments $(2010,2011,2012)$, obtained through the Cattell test at the beginning and the end of the year (the similar analysis, carried out on the material of enrolment 2013, did not display any statistically significant differences).

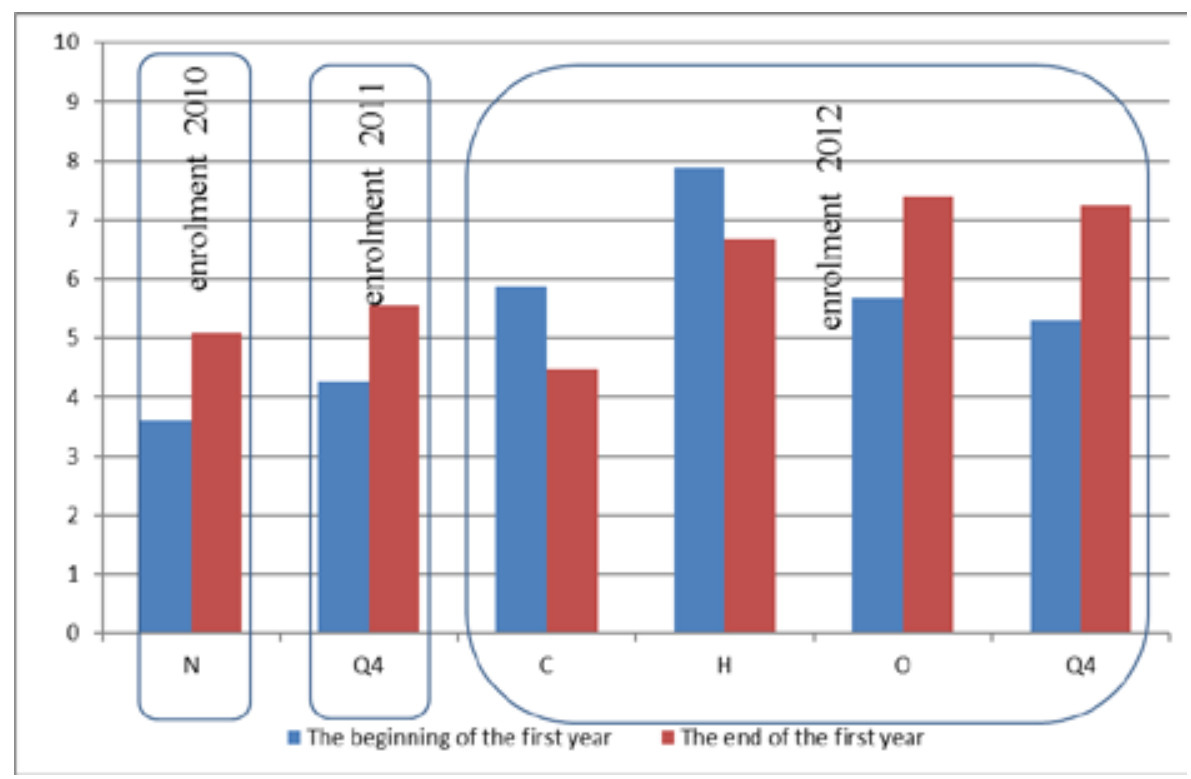

Fig. 2. Cattell test factors which displayed significant differences, the data for enrolment 2010, 2011 and 2012 (points in stens) 
As shown on Fig. 2, each course has a specific trajectory of personality changes. These changes in their turn indicate the direction of teachers' work with each course. Thus, the enrolment 2010 had a priority in the development of such characteristic as astuteness (factor N, $\mathrm{p}=.01$ ); in the work with the enrolment 2011 teachers emphasized the increase of motivation (factor $\mathrm{Q} 4, \mathrm{p}=.03$ ). Comparison of the data for the first-years of 2012 shows that changes took place in several factors. Along with heightened anxiety (factor $\mathrm{O}, \mathrm{p}=.02$ ) there is a decrease of emotional stability (factor $\mathrm{C}, \mathrm{p}=.008$ ), combined with growing insensitivity to threat (factor $\mathrm{H}$, $\mathrm{p}=.05$ ). In general, the essential tendency of these changes is towards the emotional liberation of students.

In this context it is interesting to address the situation with enrolment 2013, where, as we noted, there was no visible common tendency of personality change for the whole course. At the same time, the analysis of individual profiles displays rather significant personal transformations of most of the students. In our view, the lack of a common trajectory in personality changes may be caused by specific features of the teaching process. That is, previous enrolments had been taught by several acting teachers simultaneously (between 2 and 5 people), mainly men with considerable acting experience, whereas the enrolment 2013 was under the guidance of only two tutors (a man, an experienced tutor, and a woman, a talented actress who had never taught earlier). Presumably, the limited number of teachers who lead the acting technique made it harder for students to get feedback on the purposes of the teaching process. Additionally, the teachers also found themselves in a situation where their possibility to share students' progress with colleagues was restrained.

\section{Personal characteristics}

\section{of successful and unsuccessful students}

In this section we will observe those personal characteristics which differentiate between successful and unsuccessful students. That is, successful ("strong") students are defined as those who got positive grades in acting technique in the of the first year (66 people), and the unsuccessful ("weak") group is represented by students who were expelled at the end of the first year (26 people). During the analysis we

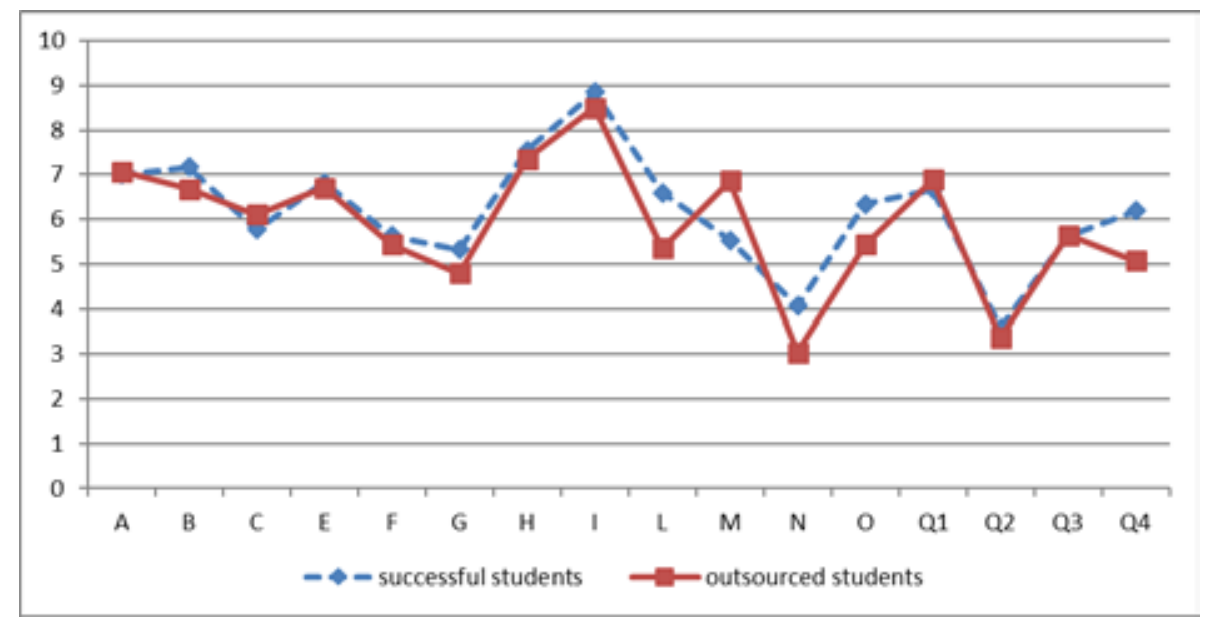

Fig. 3. Average summary personality profiles of the Cattell test for successful and outsourced students (points in stens) 
will pay attention to two points: 1) comparison of personal characteristics between the students who passed and who got outsourced; 2) analysis of both groups' personality dynamics during the whole year, which will allow to reveal the common tendencies of positive personal changes among "strong" students as opposed to the weak ones.

After comparing the profiles of successful and outsourced students we were able to underline 4 factors which have significant discrepancies: factor L "suspicion" ( $p=.01)$, factor $\mathrm{M}$ "dreaminess" $(\mathrm{p}=.004)$, factor $\mathrm{N}$ "diplomacy" $(\mathrm{p}=.04)$, factor $\mathrm{Q} 4$ "tension" $(\mathrm{p}=.002)$. Below the essential features of these differences will be described.

The expelled students are more credulous, dreamy and laidback in their behavior, and also less tense than those who continued the studies. At first it may seem unexpected, since imagination (factor $\mathrm{M}$ ) is traditionally considered one of the main characteristics of a creative talent, especially in acting. This is supported as well by our research in 1976, when high values in factor M (“dreaminess") were one of the key features of a successful theatre student's personality, whereas high values in factor L ("suspicion") implied a reason for sending down (Sobkin, 1984). Today the opposite tendency is observed: high values in suspicion and averages ones in imagination characterize successful future actors. In our opinion, in the modern situation high degree in factor M ("dreaminess") do not as much represent a well-developed and lively imagination, as they indicate immersion in one's inner illusions and images, which is as well noted by the authors of the test (Kapustina 2001, Cattell, 1976). This prevents students from understanding criticism and remarks of teachers, to shift their line of acting work, and so on. As for the factor Q4 ("tension"), as was marked before, its positive pole indicates a high level of motivation and overall energy. Higher values in factor $\mathrm{N}$ (“diplomacy") and factor $\mathrm{L}$ ("suspicion") among successful students should be viewed as complementary. High values in factor $\mathrm{N}$ display such personal features as the ability to conduct oneself well in a group, stratagem, astuteness, caution (Cattell described this pole as "Machiavelli pole", which defined an ability to reflect on the position of another person during personal interaction (Kapustina 2001, Cattell, 1976)). Low values indicate spontaneity, frankness, simplicity. Persons with high values in factor $\mathrm{L}$ are defined as cautious, often egocentric, and at the same time independent and self-sufficient in social behavior. The negative pole of this factor is described by such features as openness, tolerance, tractability. According to the authors of the test (Kapustina 2001, Cattell, 1976), both factors in question characterize the way a person treats other people. A combination of high values in factors $\mathrm{N}$ and $\mathrm{L}$ of the Cattell test indicate a pronounced social penetration, which is viewed as an ability to "read" the hidden essence of daily situations and relationships, as well as increased attention to emotions and motives of people's behavior. Yet, high points in factors $\mathrm{L}$ and $\mathrm{N}$ characterized people as inherently watchful, tense and anxious in interaction with other people. Thus, the key point in describing successful students is their ability to read emotions, motives and actions of others during personal interaction. These features are very important in grasping the image of a drama character. In this sense the mentioned complex of characteristics can be opposed to dreaminess and well-developed imagination, when the character's image is not attached to logic of their personal and social behavior.

Having described the difference between "strong" and "weak" students, we shall address the analysis of the dynamics of personality changes within these groups. 
Figures 4 and 5 display the changes of personality profiles of "strong" and "weak" students in the first year of studying.

As is clear from the figures, among the group of "weak" students there is no significant change in the personal profile comparatively to the period of entry exams. On the other hand, "strong" students demonstrate a pronounced dynamics in the three factors: $\mathrm{O}$ "anxiety" ( $\mathrm{p}=.01), \mathrm{Q} 4$ “tension" ( $\mathrm{p}=.02)$, and $\mathrm{Q} 1$ "radicalism" $(\mathrm{p}=.02)$. It is worth noticing these general tendencies fall completely in the line of the dynamics discussed in Section 1.

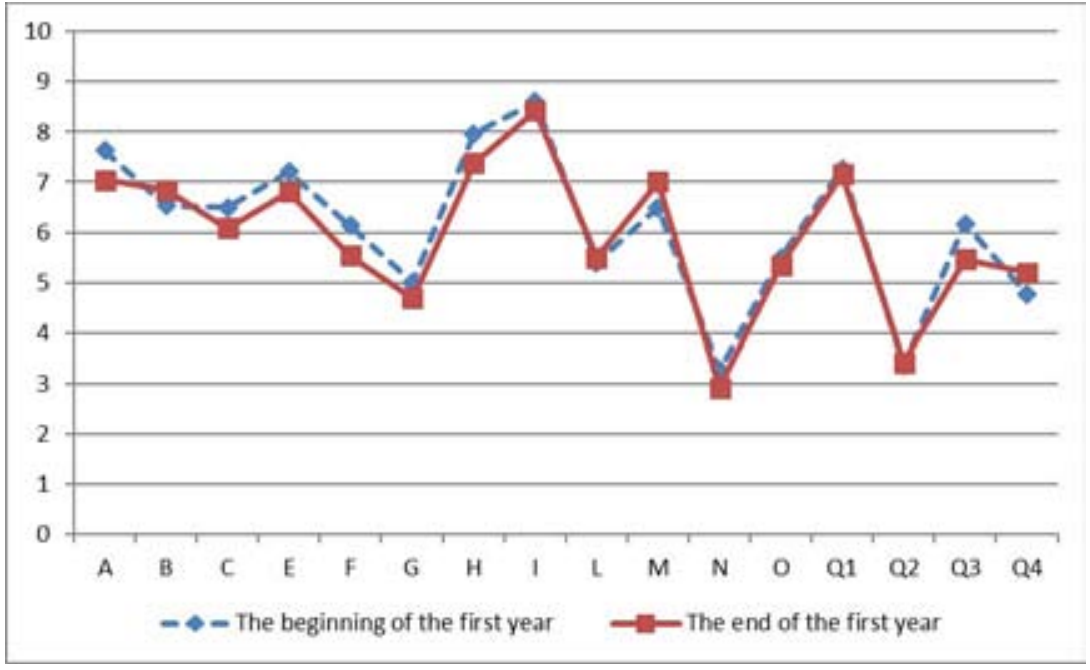

Fig. 4. Average Cattell test profiles for the group of "weak" students at the start and at the end of the year (points in stens)

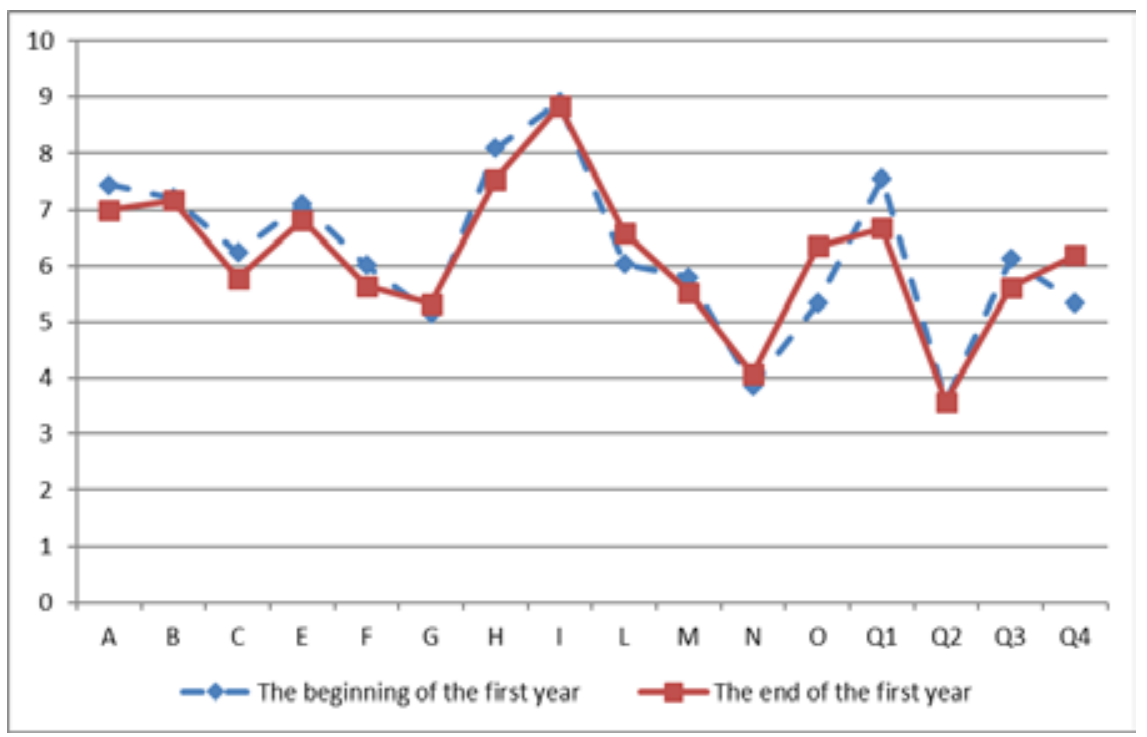

Fig. 5. Average Cattell test profiles for the group of "strong" students at the start and at the end of the year (points in stens). 
To sum up, the comparison of successful and unsuccessful students confirms that the successful group generally is more sensitive to those expectations and demands, which are applied by teachers during the first year of studying. As for the unsuccessful students, they prove to be resistant to the pedagogical influence designed to help form a professional subject.

\section{Structural analysis \\ of the personality changes dynamics of acting students}

Studying in a theatre college implies the influence of several various characteristics. Among them are special features of teaching techniques, the change of the usual life situation since the college works as a boarding school, the type of relationship in the student group as well as with teachers. At the same it may be supposed that exactly the particular qualities of the studying activity determine the main line of personality changes for theatre students. In the first two sections we analyzed material concerning the average Cattell test profiles in the groups of "strong" and "weak" students. At the same time, it is likely that not only the average personality profiles change, but there take place also structural readjustments, related to certain personal characteristics. Exactly these new connections, a sort of personality complexes, will be analyzed in the section 3 .

For this purpose a research was conducted, which revealed connections between personal characteristics of acting students. It was based on a procedure of factor analysis according to the Cattell questionnaire 16 PF. In the first factor analysis we worked over the matrix of students' individual profiles before entering the college. In the second one the procedure was applied to the data obtained by the Cattell test in the end of the first year. This stage of the research encompassed only successful students. The Tables 1 and 2 below briefly represent the results of the first and the second factor analyses.

Before interpreting the results, two points should be emphasized. Firstly, as may be seen in the tables above, the number of detected factors was reduced from 6 to 5, which may be interpreted as the increase of structural cohesion between personal characteristics by the end of the first year. Secondly, it is important to pay attention to those two factors which have a rather stable (invariant) structure for theatre college students. Below these factors are discussed in more detail.

The first of them (F1 in Table 1 and F2 in Table 2) is bipolar. It determines an opposition which may be called "anxiety/self-control". The positive pole of this factor includes such characteristics as high tension (Q4), suspicion $(\mathrm{L})$, anxiety $(\mathrm{O})$. The negative pole is represented by self-control (Q3). The structure of this factor is almost the same as the structure of the Cattell test secondary factor "anxiety". This secondary factor described anxiety in its regular sense, which is also sometimes interpreted as dissatisfaction with oneself. At high values it may reduce productivity up to its entire blockage. The negative pole is represented by only one characteristics Q3 "selfcontrol". Its wider description includes such features as determination, willpower, ability to control emotions and such.

The second invariant factor (F6 in Table 1 and F5 in Table 2) is unipolar and may be defined as "emotional openness". This factor combines high values in factors I ("sensitivity") and factor A ("sociability"). This factor, in our view, determines a lively, vibrant emotionality which is common for people gifted in acting. It also combines two important characteristics which differentiate acting students from the control group (Sobkin, Feofanova, 2012): readiness for an emotional personal contact and openness to sympathy and compassion. 
Table 1. The value of the detected factors in the beginning of the first year (invariant factors detected at both the start and the end of the year are in color)

\begin{tabular}{|c|c|c|c|c|c|}
\hline \multicolumn{6}{|c|}{ The beginning of the year } \\
\hline F1 11,5 \% & F2 11,6\% & F3 $11,6 \%$ & F4 11,0 \% & F5 9,5\% & F6 8,7\% \\
\hline $\begin{array}{c}\mathrm{O}+.83 \\
\mathrm{Q} 4+.82 \\
\mathrm{~L}+.67\end{array}$ & $\mathrm{Q} 2+.86$ & $\begin{array}{l}\mathrm{E}+.77 \\
\mathrm{Q} 1+.75\end{array}$ & $\mathrm{G}+.84$ & $\begin{array}{c}\mathrm{B}+.70 \\
\mathrm{~F}+.68\end{array}$ & $\begin{array}{l}\mathrm{I}+.77 \\
\mathrm{~A}+.72\end{array}$ \\
\hline Q3+..58 & $\mathrm{H}+.-75$ & & $\mathrm{M}+-.81$ & $\mathrm{~N}+-.52$ & \\
\hline
\end{tabular}

Table 2. The value of the detected factors in the end of the first year (invariant factors detected at both the start and the end of the year are in color)

\begin{tabular}{|c|c|c|c|c|}
\hline \multicolumn{5}{|c|}{ The end of the year } \\
\hline F1 16,2\% & F2 $15,3 \%$ & F3 $14,2 \%$ & F4 11,0 \% & F5 8,8\% \\
\hline $\begin{array}{c}\mathrm{H}+.77 \\
\mathrm{E}+.70 \\
\mathrm{~F}+.67\end{array}$ & $\begin{array}{c}\mathrm{Q} 4+.77 \\
\mathrm{~L}+.76 \\
\mathrm{O}+.52\end{array}$ & $\begin{array}{l}\mathrm{G}+.72 \\
\mathrm{~N}+.65\end{array}$ & $\mathrm{~B}+.56$ & $\begin{array}{c}\mathrm{I}+.81 \\
\mathrm{~A}+.58\end{array}$ \\
\hline $\mathrm{Q} 2+-.76$ & $\mathrm{Q} 3+-.75$ & Q1+-.65 & $C+-.68$ & \\
\hline
\end{tabular}

Thus, both invariant factors represent a specific feature complex which is a basis for successful acting students. These factors are, again, "emotional excitability/control" and "emotional openness". Other personality features detected by the Cattell test are liable to considerable transformations, uniting throughout the year into some peculiar complexes. The Table 2 represents them in more detail.

Factor F1 (contribution to the total variance $16,2 \%$ ) has a bipolar structure. Its positive pole combines scales H ("courage"), E (“domination"), F ("expressiveness") and may be labeled as "extraversion". The negative pole of this factor shows "nonconformity". Thus, the positive pole unites sociable, open students who are ready for teamwork. At the opposite pole we find students with independent and self-sufficient point of view (Q2), who at the same time do not strive for leadership and prefer a limited number of social contacts. Thus, considering these factors' value in the average Cattle test profile, we can conclude that by the end of the first year a feature complex is formed which ensures students' readiness and activity in social interaction and teamwork. In other words, it is on one hand readiness to be in a competitive environment, and on the other hand openness to social interaction.

Factor F3 (14,3 \%) is also bipolar. The opposition which it presents is "social compliance/ radicalism". The positive pole of this factor displays very high values for "moral norm" $(\mathrm{G})$ and diplomacy $(\mathrm{N})$. At the negative pole there is radicalism (Q1). As we see, there is an opposition between a desire to comply with social norms, responsibility (G), astuteness and prudence $(\mathrm{N})$ on one hand, and free-thinking, experimenting, distrust to authorities (Q1) on the other hand. Thus, the complex determined by this factor displays a very clearly marked setting at normal or abnormal behavior. Generally it may be denoted as strong or weak superego. So, this factor defines the attitude to social norms: desire to comply with rules, or, on the contrary, strive for experiment, with social norms inclusively.

Factor F4 (11,0 \%) has a bipolar structure "general intelligence/ high resistance to stress". The opposite pole of this factor has spacious 
intellect (B), seen as high ability to learn, quickwittedness, ability to tackle tasks. The negative pole is presented by factor $\mathrm{C}$, its high values are common for calm, composed, sometimes rigid people. This factor signifies a certain combination of formal intellect and emotional flexibility.

\section{Conclusions}

Below the results of the research are briefly summarized.

1) During the first year of studying the general direction of students' personality changes is oriented to the increase of emotional sensitivity, motivation and anxiety, as well as to the reduction of radicalism;

2) The major differences between successful and unsuccessful acting students appear in directions of personality changes throughout the first year. The first important point is the fact of change itself: students who remain static or demonstrate individual changes, which do not coincide with the group tendency, are less successful. As to the common direction of changes, it is oriented to the improvement of emotional sensitivity, increase of motivation and deeper trust towards teachers' authority. The important role is also played by students' serendipity which allows them to be guided by real motives and emotions of partners and characters.

3) The structural analysis of personal characteristics of successful students enabled us to determine two invariant factors: "emotional excitability/control" and "emotional openness", which represent two mandatory features of a successful actor. Other personality scales are subjected to transformation under the influence of external factors and teaching techniques.

\section{Acknowledgements}

The authors thank the People's Artist of USSR O.P. Tabakov for the initiation and support of this project.

\section{References}

1. Cattell R.B., Eber H.W. \& Tatsuoka M.M. Handbook for the Sixteen Personality Factor Questionnaire (16 PF). Champaign IL, Institute for Personality and Ability Testing, 1970. 249 p.

2. Kapustina A.N. Multifactor personal questionnaire by R. Cattell [Mnogofaktornaya lichnostnaya metodika R. Kettella]. Moscow, Rech', 2001. 112 p.

3. Sobkin V.S. Experience of research in personal characteristics of the student-actors [Opyt issledovaniya lichnostnyh harakteristik studentov-akterov]. Moscow, GITIS, 1984. pp. 22-37.

4. Sobkin V.S., Lykova T.A. Personal characteristics of students in selection to Theater College: gender aspect [Lichnostnye osobennosti pri otbore studentov $v$ teatral'nyi kolledzh: gendernyi aspekt]. 2014.

5. Sobkin V.S., Feofanova T.A. (2012) Personal characteristics of a student-actors of various generations: invariance and variability/ Voprosy psihologii (4) 32-47.

6. Vygotsky L.S. To the question about the psychology of creativity of the actor [K voprosu o psihologii tvorchestva aktera]. Moscow, Pedagogika, 1984. pp 319-328. 


\title{
Особенности личностных изменений студентов
}

\author{
на этапе первого года обучения
}

в театральном колледже

\author{
В.С. Собкин, Т.А. Лыкова \\ Российская академия образования \\ Россия, 119121, Москва, ул. Погодинская, 8
}

В статье представлены результаты лонгитюдного исследования личностных особенностей студентов-актеров, которое осуществляется на базе Московского театрального колледжа под руководством народного артиста СССР О.П. Табакова. Исследование проводится с 2010 года по настоящее время и продолжает иикл исследований авторов, начатый в 1976 г. Представлены результаты, полученные с помощью опросника Р. Кеттелла 16 РF на материале опроса 96 студентов театрального колледжа. Обсуждается динамика личностных изменений первокурсников, различия между успешными и неуспешными студентами, приводятся результаты структурного анализа личностных характеристик по тесту Кеттелла. Полученные материалы показывают, что в течение первого года обучения общее направление личностных изменений студентов-актеров ориентировано на повымение эмочиональной восприимчивости, мотивации и тревожности, а также на снижение радикализма студентов; наиболее существенные отличия между успешными и неуспешными студентами-актерами проявляются в направлении личностных трансформаций в течение обучения на первом курсе. Важным моментом является сам факт личностных изменений: студенты, демонстрирующие статичность или индивидуальные изменения, не соответствующие общим групповым тенденциям, являются менее успешными. Структурный анализ личностных характеристик успешных студентов позволил выделить два инвариантных фактора - «эмочиональная возбудимость/регулировка» и «эмочиональная открытость», фиксирующих обязательные для успешного актера личностные особенности. Другие личностные шкаль подвержены трансформациям под влияниям внешних факторов и педагогических воздействий.

Ключевые слова: актерская одаренность, личностные характеристики, психология творчества, профессиональный отбор.

Научная специальность: 13.00.00 - педагогические науки, 19.00.00-психологические науки. 